\title{
РАЗВИТИЕ КРЕАТИВНОГО МЫШЛЕНИЯ НА ОСНОВЕ ТРЕНИНГА В ПРОЦЕССЕ ОБУЧЕНИЯ ИНОСТРАННОМУ ЯЗЫКУ СТУДЕНТОВ НЕЯЗЫКОВЫХ ФАКУЛЬТЕТОВ
}

\section{DEVELOPMENT OF CREATIVE THINKING BASED ON TRAINING IN THE PROCESS OF TEACHING A FOREIGN LANGUAGE TO STUDENTS OF NON-LANGUAGE FACULTIES}

\section{E. Razumovskaya L. Mikheeva L. Sidorkina}

Summary: The relevance of the research in the article is due to the fact that in the modern educational process of Russian universities, the most significant is not the assimilation of ready-made knowledge of a foreign language, but the development of students' thinking methods that ensure the production of new knowledge and skills. The aim of the research in the article is to generalize and implement in practice the methodology for the development of creative thinking based on training in the process of teaching a foreign language to students of non-linguistic faculties. The study used theoretical and empirical methods. Based on the results of the study, the article presents theoretical and practical provisions on the use of methods for the development of creative thinking based on training in the process of teaching a foreign language to students of non-linguistic faculties.

The theoretical significance lies in the fact that the results of the study complement the theory and methodology of teaching a foreign language ... The practical significance of the research consists in: the development of an assessment toolkit that allows to determine the effectiveness of the development of creative thinking on the basis of training in the process of teaching a foreign language to students of nonlinguistic faculties; in the introduction of an appropriate set of trainings in a foreign language into the educational process.

Keywords: creative thinking, training, the process of teaching a foreign language, students of non-language faculties, intercultural communication, intercultural interaction, pedagogical conditions, problematic and heuristic situations.

\section{ВвеАение}

A ктуальность работы обусловлена рядом противоречий, сдерживающих решение проблемы развития креативного мышления на основе тренинга в процессе обучения иностранному языку студентов неязыковых факультетов: между современными требованиями общества к специалистам с высокой креативностью

\author{
Разумовская Елена Александровна \\ К.с.н., дочент, Институт международного права и \\ экономики им. А.С. Грибоедова \\ razumovskayal@mail.ru \\ Михеева Людмила Дмитриевна \\ старший преподаватель, АНО ВО «Московский \\ международный университет» \\ mikheeva_ld@mail.ru \\ Сидоркина Людмила Сергеевна \\ Преподаватель, ГБПОУ «Колледж современных технологий \\ имени Героя Советского Союза М.Ф. Панова» \\ lykashevich@gmail.com
}

Аннотация: Актуальность исследования в статье обусловлена тем, что в современном образовательном процессе российских вузов наиболее значимым становится не усвоение готовых знаний по иностранному языку, а развитие способов мышления студентов, обеспечивающих производство новых знаний и умений. Целью исследования в статье является обобщение и реализация на практике методики развития креативного мышления на основе тренинга в процессе обучения иностранному языку студентов неязыковых факультетов. В исследовании использованы теоретические и эмпирические методы. По итогам исследования в статье представлены теоретические и практические положения по использованию методики развития креативного мышления на основе тренинга в процессе обучения иностранному языку студентов неязыковых факультетов.

Теоретическая значимость заключается в том, что результаты проведённого исследования дополняют теорию и методику обучения иностранному языку. Практическая значимость исследования состоит в: разработке оценочного инструментария, позволяющего определять эффективность развития креативного мышления на основе тренинга в процессе обучения иностранному языку студентов неязыковых факультетов; во внедрении в учебно-образовательный процесс соответствующего комплекса тренингов по иностранному языку.

Ключевые слова: креативное мышление, тренинг, процесс обучения иностранному языку, студенты неязыковых факультетов, межкультурная коммуникация, межкультурное взаимодействие, педагогические условия, проблемные и эвристические ситуации.

в международной деятельности и часто традиционными подходами к их подготовке по иностранному языку в вузе; между личностной востребованностью на творческий подход в изучении иностранного языка и недостаточной возможностью её реализации в условиях университета.

Креативное мышление в нашем исследовании мы бу- 
дем рассматривать как способность с помощью анализа, комбинации и синтеза аутентичной информации создавать новые значимые знания и формы на иностранном языке, имеющие наибольший эффект в межкультурном общении специалистов из различных сфер. Под тренингом мы будем понимать метод активного обучения иностранному языку, направленный на развитие знаний, умений и навыков межкультурного общения, а также установок на креативное мышление в профессиональном общении.

Анализ состояния проблемы развития креативного мышления на основе тренинга в процессе обучения иностранному языку студентов неязыковых факультетов приводит к выводу о её недостаточной теоретической и практической разработанности, что способствовало выбору темы исследования в статье.

\section{Обзор отечественной и зарубежной ^итературы по теме исследования}

Теоретико-методологической основой исследования стали работы по педагогике высшей школы. Особый интерес для нас представляют фундаментальные труды отечественных ученых, рассматривающих приоритет деятельностного, компетентностного и культурологического подходов в области межличностного общения, в системе высшего образования. Так, Г.М. Коджаспировой были разработаны научно - практические положения педагогики высшего образования [1]. А.Ю. Козырева в своей работе представила лекции по педагогике и психологии творчества [2]. Важным представляется исследование А.А. Деркач и С.Ф. Щербак в плане педагогической эвристики, которая обозначена авторами как искусство овладения иностранным языком [3]. Н.J. Eysenck описал историю возникновения творческого подхода в образовании [4]. J.F. Feldhusen уточнил характеристику креативного подхода в образовании: его сущность, метакогнитивные комптенции и личностные факторы в использовании [5]. D.Feldman описал методологические и методические основы освоения креативного мышления и деятельности в образовании [6]. Например, Е.Г. Алиева рассматривает вопросы креативности в зарубежной психологии [7]. В.В. Давыдов в своей работе обобщает проблемы развивающего обучения и пути их решения [8]. Г.А. Игнатьева описывает дидактику развивающего обучения [9]. Е.А. Лапп рассматривает учебно-научную и научно-исследовательскую деятельность бакалавра [10]. В работе Л.Б. Ермолаевой - Томиной рассматривается креативность как реализация потенциальных возможностей человека [11]. В.И. Загвязинский отмечает важность исследования педагогического творчества учителя [12]. Важной представляется, работа Е.В. Заика, которая посвящена изучению и разработке комплекса интеллектуальных игр для развития мышления учащихся [13]. Далее Е.В.Заика представлен комплекс игр для развития воображения [14]. В.А. КанКалик и Н.Д. Никандровым разработаны научно - практические положения педагогического творчества [15]. Л.Я. Дмитрачкова представляет сущность иноязычного образования в контексте вузовской подготовки специалистов различных профилей и его особенности [16]. Например, П.М. Горев и В.В. Утемов в своей работе анализируют сущность и специфику научного творчества, ими представлено практическое руководство по развитию креативного мышления, а также методы и приемы технологии решения исследовательских задач [17]. Г.А. Халюшовой разработана методика развития лингвистической креативности студента университета [18].

\section{Материалы и методы}

Теоретико-методологической базой исследования послужили вышеуказанные труды отечественных ученых в области педагогики, лингводидактики, коммуникативной лингвистики, методики обучения иностранным языкам на основе использования творческого подхода в образовании. В нашем исследовании использованы теоретические и эмпирические методы.

База исследования: неязыковые факультеты Института международного права и экономики им. А.С. Грибоедова, г. Москва, АНОВО «Московский международный университет», г. Москва и частично неязыковые отделения подготовки по техническим специальностям ГБПОУ «Колледж современных технологий имени Героя Советского Союза М.Ф. Панова», г. Москва.

Логика исследования состояла из следующих этапов: поисковый, который предполагал определение теоретической и методической базы исследования, изучение трудов отечественных и зарубежных ученых по психологии, педагогике, лингвистике и методике обучения иностранным языкам; опытное обучение, проверка предложенной организации творческой учебной деятельности; диагностико-оценочный, который включал анализ, систематизацию и обобщение результатов, уточнение положений и выводов исследования. Первостепенное значение отводилось тренингу развития креативного мышления в процессе обучения иностранному языку студентов неязыковых факультетов. Тренинг в опытном обучении имел свои параметры, к которым относятся: тренинговая творческая группа; тренинговый круг общения и взаимодействия; установленные правила работы в творческой группе; создание атмосферы иноязычного взаимодействия и общения; интерактивные методы обучения иностранному языку; структура и содержание тренингового занятия по иностранному языку; оценки эффективности тренинга. В ходе опытного обучения были применены следующие виды упражнений тренинга: организационные; мотивационные; коммуникативные; креативные, развития когнитивных процес- 
сов в творческой деятельности. Мониторинг развития креативного мышления на основе тренинга в процессе обучения иностранному языку студентов неязыковых факультетов осуществлялся с помощью диагностических методик. Результаты диагностики свидетельствуют о позитивной динамике уровней развития креативного мышления в экспериментальных группах. Сравнительно- сопоставительный анализ процентного распределения участников опытного обучения по уровню развития креативности на этапах констатирующей и контрольной диагностики по критерию Т-Стьюдента выявляет существенную динамику $(\mathrm{t}=4,62 ; \mathrm{t}=3,35$ при $\mathrm{p}<0,01)$. Коэффициенты достоверности различий по уровням креативности мышления в процессе обучения иностранному языку в группах позволили определить потенциал актуального развития: (уровень усвоения - Т =4,36 при $\mathrm{p}<$ 0,01), (уровень результатов - T = 5,53 при $\mathrm{p}<0,01$ ). Анализ данных по итогам опытного обучения подтверждает, что реализация выделенных нами методов, способствует решению основной задачи - развитию креативного мышления в процессе обучения иностранному языку студентов неязыковых факультетов.

\section{Результаты исследования}

Значимость исследования состоит в определении теоретических и практических положений по использованию методики развития креативного мышления на основе тренинга в процессе обучения иностранному языку студентов неязыковых факультетов: раскрыта сущность креативного мышления студента университета в области иностранного языка; апробирована методика развития креативного мышления на основе тренинга в процессе обучения иностранному языку студентов неязыковых факультетов, позволяющая организовывать процесс обучения иностранному языку, основанный на творческой познавательной деятельности в сфере своих профессиональных интересов.

По окончании тренинга в процессе обучения иностранному языку его эффективность может быть оценена на двух уровнях: усвоения и результатов. Подчеркнем, что каждый из уровней оценивались как высокий, средний и низкий. Следует особо отметить, что долгосрочный стабильный эффект развития креативного мышления на основе тренинга в процессе обучения иностранному языку студентов неязыковых факультетов дает только системное обучение. Повысить эффективность тренинга могут специальные программы закрепления навыков, помогающие отслеживать проявление новых форм взаимодействия и общения на иностранном языке в сфере профессиональных интересов.

\section{Зак^ючение}

В ходе опытного обучения подтверждена эффективность теоретических и практических положений по использованию методики развития креативного мышления на основе тренинга в процессе обучения иностранному языку студентов неязыковых факультетов. При этом педагогические условия ее применения рассматривались в качестве намеренно создаваемых обстоятельств, способствующих развитию креативного мышления студентов. В опытном обучении была применена системная диагностика определения показателей развития креативного мышления. Общий ход опытного обучения, наблюдение за возрастающей степенью активности студентов к выполнению творческих заданий на иностранном языке. Проведённое исследование не исчерпывает многообразия вопросов, связанных с рассмотрением теории и методики развития креативности в обучении иностранному языку.

1. Коджаспирова Г.М. Педагогика: учебник. - М.: Гардарики, 2004. - 528 с.

2. Козырева А.Ю. Лекции по педагогике и психологии творчества. - Пенза, 1994. - 342 с.

3. Деркач А.А., Щербак С.Ф. Педагогическая эвристика: искусство овладения иностранным языком. - М.: Педагогика, 1991. - 224 с.

4. Eysenck H.J. Genius. The natural history of creativity / H.J. Eysenck. Cambridge: Cambr. Univ. Press, 1995.-136p.

5. Feldhusen J.F. Creativity: A Knowledge Base, Metacognitive Skills, and Personality Factors / J.F. Feldhusen // J. of Creat.Beh. -1995. Vol. 29.-№ 4.-p.32-40.

6. Feldman D. Changing the world: A framework for the study of creativity / D. Feldman, M. Csikzentmihalyi, H. Gardner. Yale Press.- 1994.-146p.

7. Алиева Е.Г. Изучение креативности в зарубежной психологии / Е.Г. Алиева // Психологический анализ учебной деятельности. М.: ИП РАН, 1991. - 24 с.

8. Давыдов В.В. Проблемы развивающего обучения/ В. В. Давыдов. - Издательство: «Директмедиа Паблишинг», 2008. - 613 с.

9. Игнатьева Г.А. Дидактика развивающего обучения / Г.А. Игнатьева, В. О.Волкова, 0. П.Шишкина. — Нижний Новгород: Изд-во ННГУ, 1998. - 136 с.

10. Лапп Е.А. Учебно-научная и научно-исследовательская деятельность бакалавра: учебное пособие / Е.А. Лапп. -Электрон. текстовые данные. — Саратов : Вузовское образование, 2013. - 111с.

11. Ермолаева-Томина Л.Б. Креативность как реализация потенциальных возможностей человека. - М.: Прометей, 2001. - $218 c$.

12. Загвязинский В.И. Педагогическое творчество учителя. - М.: Педагогика, 1987. - 159 с.

13. Заика Е.В. Комплекс интеллектуальных игр для развития мышления учащихся // Вопросы психологии. - 1990. № 6. - С. 86 - 92.

14. Заика Е.В. Комплекс игр для развития воображения // Вопросы психологии. - 1993. №2. - С. 54-62. 
15. Кан-Калик В.А., Никандров Н.Д. Педагогическое творчество. - М.: Педагогика, 1990. - 144 с.

16. Дмитрачкова Л.Я. Иноязычное образование в контексте вузовской подготовки специалиста // Материалы международной научно-практической конференции «Интеграционные процессы в образовании», Ч. 1. - М.: АПКиППРО, 2006. - С. 61 - 63.

17. Горев П.М., Утемов В.В. Научное творчество: Практическое руководство по развитию креативного мышления. Методы и приемы ТРИЗ.Изд.2.М.:ЛЕНАНД,2016.-112 с.

18. Халюшова Г.А. Развитие лингвистической креативности студента университета: дис. . . канд. пед. наук/Г.А. Халюшова. Оренбург,2005. - 198 с.

๑ Разумовская Елена Александровна (razumovskayal@mail.ru), Михеева Людмила Дмитриевна (mikheeva_Id@mail.ru), Сидоркина Людмила Сергеевна (lykashevich@gmail.com).

Журнал «Современная наука: актуальные проблемы теории и практики»

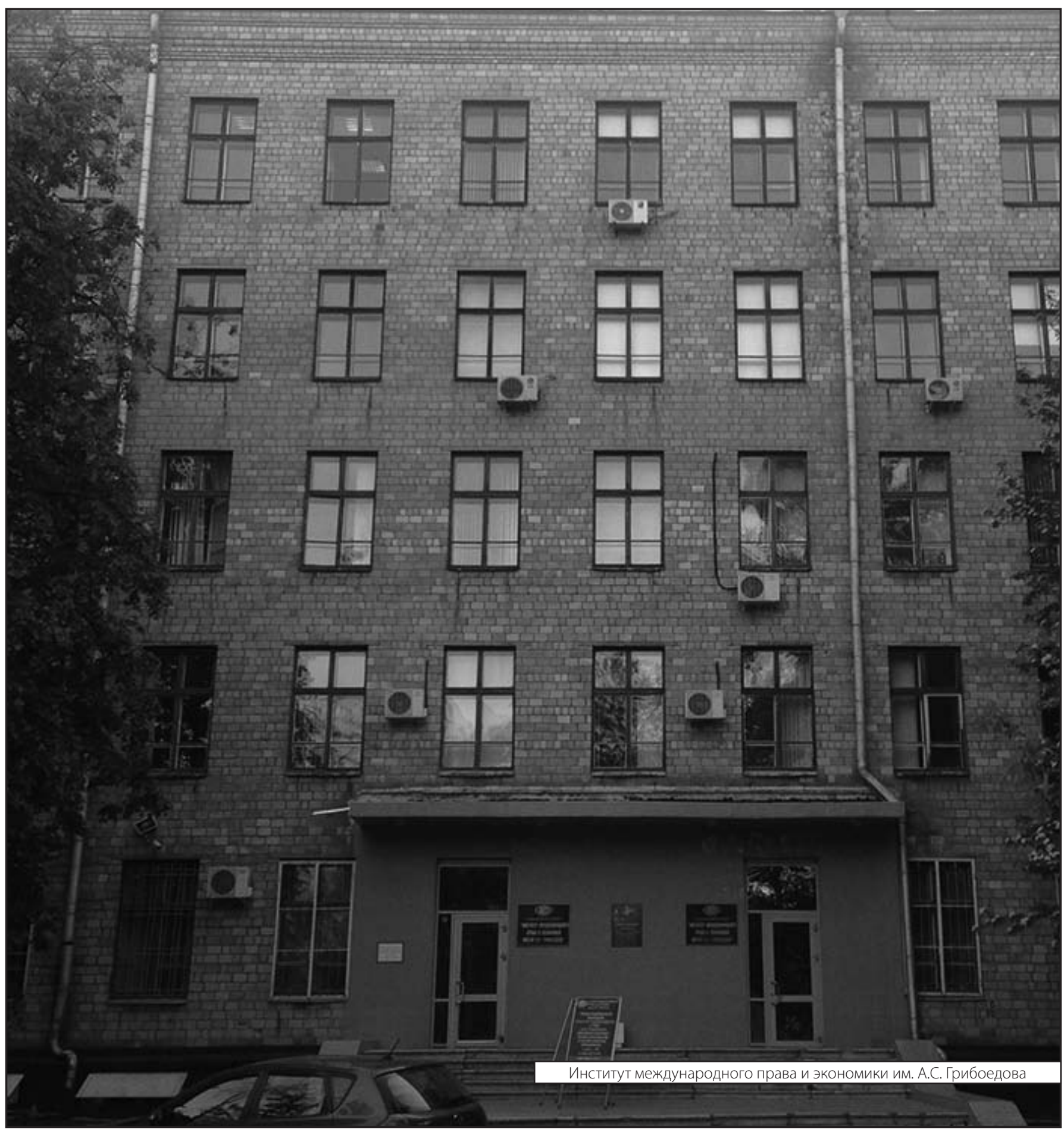

